\title{
Information Practices in Elementary School
}

\author{
ANNA LundH AND LOUISE LimberG \\ Swedish School of Library and Information Science, University College of Borås, Sweden
}

\begin{abstract}
This article presents a qualitative study that examines the roles of pedagogues in elementary schools with regard to young children's information literacy. The concept of information literacy is seen from a sociocultural perspective, as a dimension of literacy that varies in different social practices. Further, from this perspective the importance of the mediating functions of tools used in information seeking is stressed. Data was collected from a Swedish village school from one focus group interview and two individual interviews with different kinds of pedagogues. Problem-centred teaching was also observed in five forms with pupils aged 6-8. In the
\end{abstract}

analysis an overarching division or two discourses connected to information literacy emerged. On the one hand, literacy, aesthetic activities and the reading of fiction were the focus and, on the other hand, there was a focus on information literacy, utilitarian information-seeking activities and ICTtools. It is also shown that information seeking is given a certain meaning in problem-centred activities in elementary school. The authors consider that the discourses found in the empirical material might have implications for the concept of information literacy, if they are explored to a fuller extent.

\section{Introduction [1]}

The departure point for this study is an earlier qualitative study of the use of information and communication technology (ICT) in elementary schools in Sweden (Davidsson et al. 2007). In that study it was shown that the use of ICT tools was surrounded by restrictions for the pupils. Furthermore, results indicated that ICT tools seemed to threaten the teachers' and librarians' occupational identities, their authority and control, and challenged their views of the concept of childhood. A picture also emerged suggesting that students' copy-and-paste strategies, which are considered a serious problem in higher grades, may be based on pupils' experiences during the first years of school. This result confirms findings from previous research on young students' work with ICT tools involving problem-centred assignments, where it has been shown that the information seeking process is shaped by the discursive practice of school (for example, see Alexandersson \& Limberg 2003).

The discouraging results of Davidsson et al. initiated a second project to see if the picture could be differentiated. "The role of the pedagogue in pupils' construction of information literacy" was undertaken, focusing on what pedagogues [2] in elementary school actually do, rather than what they are not doing. This project also widened the scope of the previous study by taking an interest in the teachers' conceptions of their pupils' information literacy and not only of their use of ICT. Teachers' conceptions of information literacy have been explored in earlier studies (for example, Bruce 1997; Williams \& Wavell 2006), but these studies do not concern teachers for the lower age groups.

The objective of this paper is to present the results of this second project and thereby contribute

This paper is based on a presentation at the international conference ,i3: Information: Interactions and Impact', organised by the Robert Gordon University Department of Information Management, and held in Aberdeen, Scotland, $25-28$ June 2007.

Anna Lundh is Doctoral student, Swedish School of Library and Information Science, University College of Borås, SE-501 90 Borås, Sweden. E-mail: anna.lundh@hb.se

Louise Limberg is Professor, Swedish School of Library and Information Science, University College of Borås, SE-501 90 Borås, Sweden. E-mail: louise.limberg@hb.se 
to the understanding of information practices in elementary school. In this way we wish to lay a foundation for further studies on information literacy in the social practices of elementary school.

To fulfil the objective of the study the following questions have been formulated:

- How do pedagogues describe and organize young school children's information-seeking activities in elementary school?

- What do these descriptions and ways of organizing teaching imply for what it means to be an information literate pupil in elementary school?

These questions will be answered below by an analysis of interviews with pedagogues as well as observations of more or less independent work in young school children's classrooms.

\section{A sociocultural perspective on information literacy}

The concept of information literacy has been debated and its meaning is not self-evident. It is used in various ways, sometimes as a theoretical concept, but it also has a close relationship to, and is sometimes used interchangeably with, user education at academic and school libraries (Bawden 2001, 235). The least that can be said is that the concept has to do with information seeking and use.

In this study we view information literacy from a perspective based in sociocultural theory, a pedagogical theory which emanates from the Russian psychologist L. S. Vygotsky (1978). This theoretical stance can be said to be a part of what Olof Sundin $(2008,27$; Sundin 2005a, 2005b) formulates as "A new emerging framework on information literacy". According to Sundin, this framework emphasizes the social aspects of information literacy and information seeking and problematizes a view of information as a neutral entity. The framework stems from a critique of the view of information literacy as something that can be reduced to a few general skills which can be measured in an unproblematic way.

This framework offers a view of information literacy as a dimension of modern literacy. To become literate can, from a sociocultural perspective, be seen as a way of learning how to communicate within a social practice (Gee 2002). Roger Säljö
(2005, chap.7) suggests that learning in this sense today also includes learning how to seek and use information. Further, Jack Andersen claims, in an article on information literacy, that "... a literate person in late modern society is not someone with reading and writing skills only. $\mathrm{He} /$ she must also be in possession of information seeking skills as late modern society and its information structures demand this" (2006, 217). Young school children are usually engaged in trying to participate in literary social practices and much of their time in school is devoted to trying to become literate. In this study we focus on activities connected to this learning and especially to related information seeking activities.

A basic assumption in the sociocultural perspective is that all learning is situated in different practices (Säljö 2000, chap. 6). Teachers are actively involved in shaping the school's social practice. Thus, the social practice of the school, which is an unfamiliar practice for elementary school children, emerges as important for the ways in which children construct information literacy. This also means that information literacy has different meanings in different social practices (Tuominen, Savolainen, \& Talja 2005).

Within sociocultural theory the importance of tools (Vygotsky 1997) or mediational means (Wertsch 1998, 17) in human thought is stressed. To understand human action you need to consider the intellectual and physical tools that are used, such as language or ICT tools, and the knowledge built into these tools. This also implies that the world is always mediated through the cultural tools used by people (Säljö 2000, 2005). Within Sundin's framework the information literacy concept has been criticized because it conceals that the tools used in information seeking and related activities have these mediating functions (2008). For example, James Marcum (2002) criticizes underlying assumptions in the information literacy notion which stem from a view of information as a neutral entity which is transmitted through other people or information systems to become knowledge in the individual. From a poststructural perspective Cushla Kapitzke (2003) shows that the information literacy discourse is built on traditional positivist epistemological assumptions derived from the industrial sector (Bawden 2001, 237). Kapitzke argues that today's educational systems have taken over the "discourses of tech- 
nology and the global market economy" $(2003,41)$ by cherishing the concept of information literacy espoused therein.

Also Christine Pawley (2003) and Michelle Holschuh Simmons (2005) claim that information literacy instruction needs to adopt postmodern epistemologies and highlight the social, economical and political conditions of the publication of documents. The same kind of reasoning can be found in the article by Andersen $(2006,225)$ where information literacy is seen as conceptually linked to socio-political skills: "Basically, information literacy must be grounded in an understanding of how the documents stored in the information system one uses are produced as a result of some generic communicative activities in society." In this view of information literacy, information-seeking activities are not seen as merely technical activities, but also as "communicative participation in different social practices" (Sundin \& Johannisson 2005, 37).

Thus, a sociocultural perspective on information literacy offers a view on information literacy as a dimension of literacy, a way of analyzing what it means to be information literate in different practices, but also a critical analysis of the concept itself.

\section{Empirical framework}

For this study, data was collected from a Swedish village school that had pupils ranging in age from 6 to 16 years old. The school was chosen because it has concentrated on the development of the school library which is staffed by a specially trained teacher-librarian. [3]

Since the data collection was guided by the ambition of creating an understanding of the work of the pedagogues, the pedagogues themselves have been an active part in the construction of the empirical framework. The study began with a focus group interview with teachers working with preschool [4] pupils and first- and second-formers (68 year-olds). The discussions were focused on the teachers' views of information literacy, [5] of pupils' work with problem-centred assignments and of the school library in a pedagogical perspective.

Further, the pre-school group (6 years olds) and the first-formers (who were 7 years old) were ob-served when both groups were working with a "fruit theme". The second formers (who were
8 years old) were observed when working individually and in-group with "research themes" chosen by the pupils themselves. Spontaneous interviews with both pedagogues and pupils took place during the observations. Two other important pedagogues were identified during the data collection: the librarian and an ICT assistant. Individual semi-structured interviews were conducted with these two persons. In these interviews, three documents were brought up by the participants: the goals of the school library, a plan for developing the library, and material for lessons on Web-based information seeking. These documents have been included in the data analysis.

The focus group interview and the two individual interviews were recorded and transcribed in their entirety. During the observations field notes were taken and written up in detail shortly afterwards. The material has been analyzed in two stages related to the different kinds of data collection methods. The analysis was guided by the ambition to understand the information practices of elementary school, first in written and spoken statements about information seeking activities and thereafter in the observations of such activities in the classrooms and in the school library.

For a summary of the material analyzed in this study see the Appendix.

\section{Findings}

In the analysis we have found an overarching division or two discourses related to information literacy. This overall division can be regarded as a division between literacy and information literacy; information literacy seems to be separated from literacy, rather than a dimension of it. On the one hand, there is a tradition focusing on aesthetic activities and the reading of fiction. On the other hand, there is also a focus on utilitarian information seeking activities and ICT-tools. This appeared in the ways that problem-centred work was organized in the different classrooms; there were significant differences between the social practices of the lower forms (pre-school group and first form) - where working methods are influenced by pre-school pedagogy - and the higher forms (second form). The two discourses can also be seen as connected to the different pedagogues' occupational identities. In the following these results are described in detail. 


\section{Focus on literacy}

The teachers, as well as the librarian, stressed the importance of their work in teaching the children' to read and write. The literacy aim permeated the work in the classrooms and can be seen as a dominant activity which almost all other activities were connected to. In the interviews with the teachers and the librarian this focus on literacy was evident.

One consequence of this focus is that copy-andpaste strategies were seen as necessary features in the work of the young children. The teachers described the youngest children's research activities as necessarily including the copying of other texts:

Primary-school teacher: Well, for some of them, the copying of a text is a goal in itself [...] because then you learn how to write.

Another part of the work with literacy was the reading of fiction. At this particular school the librarian ran a reading project, which meant that all pupils read fiction a certain amount of time every day. Applied to the youngest children the librarian expressed the view that her most important task was to work with the children's reading and to try to stimulate a passion for fiction. She stressed what she described as the positive effects of reading books, a subject she took up at parents' meetings and which was also visible in the plan for the development of the library.

Librarian: You should have the language, you should have the fantasy and the understanding and the empathy - you will get it all when you read.

Because of the concentration on fiction and the reading of books, the librarian said that she devoted much less time to traditional library instruction at the time of the interview than she had done a few years previously with the youngest children.

The teachers also highlighted the positive effects of fiction. They meant that today's children are more stressed than children in earlier times and that the reading aloud of stories could function as a counterbalance to the children's stressful everyday lives.

\section{Focus on information seeking}

The focus on literacy in general did not mean that issues on information seeking were left out in the interviews. Even though the librarian's role as a co-worker in questions about fiction emerged in the teacher's discussions of their use of the school library, it was evident that the library also was important with regard to other kinds of assignments.

Nevertheless, issues concerning the younger pupils' navigation on the Internet did not seem to be handled by the librarian. The teachers identified difficulties with their own Web-based information seeking, and they described problems finding written material that suited the younger children on the Web. The Web seemed to be used mostly for finding pictures that could be used by the children. For the second-formers the teachers have arranged lessons in the library held by an ICT assistant who had a technical background as an owner-manager. During these lessons the children were supported in information seeking on the Web as well as with other ICT related skills such as using word processing programs. These lessons were separated from the rest of the work in the classroom. Usually these kinds of lessons were reserved for older pupils, but the children's use of the Internet at home had made the pedagogues realise that issues concerning navigation on the Internet had to be discussed at school as well:

ICT assistant: [...] the children are using computers at home and you feel that school has an obligation to make them mature enough to use this tool. Well, it just goes downwards in age.

During the lessons the ICT assistant showed different search engines and gave the children tasks which he constructed himself, some of them factoriented with 'right answers' (e.g. "What is the five paces of the Icelandic horse called?"), but also questions that had more to do with the children's everyday lives, such as how to find timetables for the buses in the village. Teacher experiences of difficulties in finding material suited for younger children were not evident in the discussions with the ICT assistant. Rather, he claimed that the children can solve quite advanced tasks if they get the right kind of support. 
Thus, in the pedagogues' discursive practice regarding young children's information literacy a view of information literacy as separated from literacy appears. Even though all of the pedagogues found it important to work with information seeking and evaluation of the sources with the children, this work was partly separated from the work with literacy, which to a large extant seemed to be about the reading of fiction.

\section{Pre-school group and first grade}

During the observations of the "fruit theme" it emerged that the main aim of the theme was to encourage cooperation between the different forms. Therefore, the fruit in the fruit theme functioned more as a node around which to organize the pupils' activities, rather than an important topic in itself.

The school days devoted to the theme were always organized in similar ways. After a morning assembly in every classroom, all children had a music lesson where most songs were about fruits and one of the pre-school teachers or the older children read a story where fruit was more or less in focus. After a break, the children were divided in mixed groups according to a system of sponsorship. They were working together with mostly aesthetic activities such as painting, writing fairy tales, making fruits with potter's clay or doing prints with apples. Before breaking-up for the autumn holiday the children watched the Disney version of Snow White (which the teachers had chosen because of the appearance of an apple in the story).

In this theme, events of information seeking were rare, at least information seeking through formal information systems. Neither the library nor the computers were actively used during the theme. All activities were initiated and led by the teachers who had already prepared the material used by the children. Overall, the children's own written language was not in focus during the theme. One exception was when the children wrote and painted stories together in pairs. A common way to do this was to tell the story to one of the teachers who wrote it down for the children to copy.

The teachers explained that the theme was organized on account of the pre-school children and that it would have been organized differently if it had been a theme with first-formers only. More self initiated work was not in question yet, but the teachers meant that some of the first-formers might be ready to work in such a manner later on.

\section{Second grade}

During the observations in the second-formers' classroom the children were given more responsibility for choosing topics to work with, and information-seeking activities were an important part of the work. Earlier, the teachers had organized common themes in their groups, but this term they had decided to arrange things differently. During the focus group one of them explained:

Primary-school teacher: [...] But now we said that we want to learn, sort of, where can I learn about things? I can go to the library, I can use the web, I can ask grandma, I can call a cousin who is good at this... So we want to go through this in the proper way. So it's not that we're focussing on, not just a certain area, but then I can use it everywhere.

Later, the teachers explained that their idea to work methodically with information seeking had been influenced partly by the requirements of the curriculum, but also by a lecture held by a wellknown spokesman from a chamber of commerce. He had talked about what he considered school children needed to learn in preparation for working life, and he had emphasized the importance of children's ability to solve problems.

In one of the classes the introduction to this new way of working with problem-centred assignments was observed. The teacher gathered the children in a ring on the floor and together they talked about research and where researchers work. Most of the examples discussed were taken from the natural sciences, for instance, medicine and palaeontology. After these initial discussions the teacher started to ask questions about how you go about doing research and during this discussion the teacher drew a mind map which resulted the following headings: "Ask somebody you know", "Go to the library", "Internet", "Colleges and universities", "Museums", "What do I know myself".

Even though these various forms of information seeking were discussed initially, the children's information seeking was less varied when they were working with their own research. In both 
classrooms the children's work was organized in a certain order: First the individual child chose a topic, usually very broadly defined, such as "the body", "bears", "ice cream" and so forth. Sometimes this choice had to do with something the children already had worked with, but generally their choices seemed to be quite random. If two or more children had chosen similar topics they were asked to work together by the teachers. Thereafter the children started to seek information for their task. This often included a visit to the school library and/or searching the Web through Google. Sometimes the teacher had printed out material from the Web for the children. Below two occasions of children's information seeking are described, first when a girl was going to the library with two classmates and later when a boy was searching for pictures using Google Image Search.

The three children, two girls and a boy walked the short distance over the schoolyard to the library. Here they told the librarian that they "want to find a book each to do research about". [...] When the librarian sat down with the two girls she asked them questions about what they had done research on before and they told her about their research on football and bumblebees. Thereafter they started to talk about new possible topics. One of the girls suddenly burst out "hens" and the librarian almost immediately handed her two books with texts about hens. Then the librarian and the other girl went together to a shelf with books on sports and they started to browse. The girl found a book about ice hockey, but the librarian insisted that it was too difficult for the girl. Instead the librarian asked the girl to think of other possible topics and then she gave her a book about "invented" sports before she helped the other children at the reference desk. The girl flipped through the book, but didn't find it interesting. She waited while the librarian helped the other children and when they started to speak again the girl had chosen to do research on "former times". The librarian walked with the girl to the history shelf and picked her a book about the Stone Age. First the girl objected because she knew that one of her classmates was using the same book, but the librarian had to rush because a whole class who had an appointment entered the library. (Field note, October 11, 2006)

The other situation concerns a boy who wants a picture for his research on ice cream:

The teacher told him to try to find one through Google where he knew how to choose Image Search and he tried with the entry "ice cream" which is "glass" in Swedish. The results yielded a number of pictures of various sorts of glass, but no ice cream. The teacher noticed his problems and helped him to try "ice cream" instead. The boy browsed through the results and chose the first one which he printed out with some help from the teacher. He took the picture from the printer and started to colour it. [...] Later, during the same lesson, the boy encountered similar problems when he was trying to find a picture on potato crisps, which is just "chips" in Swedish and where the results showed pictures of chips. Again, the teacher helped him to find an appropriate keyword. (Field note, November 13,2006$)$

What we can see from these observations is that the children's research questions were determined by the material that the teacher or the librarian found suitable for the specific child and that this material was restricted to a few sources. Thus, the children did not get very much support during the important phase where the problem area was defined, mainly because of the great number of children that required the pedagogue's attention. We can also see how the Web was used for searching for illustrations and that the children needed a lot of support during their searches.

The next phase in the children's research process seemed to be a copying phase, which included making photocopies of several pages from a chosen book and thereafter highlighting sentences which were judged to be important either by the child or by the teacher. Afterwards, the child was supposed to copy the text onto a ruled paper which started with the sentence "I'm doing research on...." Copying strategies were evident when the children later presented their research; they read from their papers things like "This is how small you are compared to a Tyrannosaurus Rex" without showing any pictures. The children presented their work by reading aloud from their papers, even though the teachers tried to encourage the children to speak more freely. This made the presentations fragmented and hard to follow. It was evident that the teacher had a very important role in discussing the contents of the presentations with the children to make them more comprehensible.

The analysis of the field notes from the observations of the second-formers shows a discrepancy between the teachers' view of information literacy and the way they organized pupils' independent work. Even if it was apparent through the observations that one of the teachers had the ambition to develop pupils' understanding of the social organization of knowledge (Andersen 2006), the social practice of problem-centred assignments im- 
plies a certain way of working which does not include all kinds of sources. Rather, information seeking is given a particular meaning in classroom practice and is directed mainly towards books from the library and pictures from the Web which are copied.

We can also see that to work with self initiated problems is a practice which the children start to work with when the pedagogues judge them to be old enough or if they are seen as high-achievers. Therefore, the children's own information seeking is not central in the pre-school class or in the first form.

\section{Discussion}

Through the analysis of the material the two research questions can be answered.

How do pedagogues describe and organize young school children's information seeking activities in elementary school?

In relation to information literacy two discourses seem to meet, or perhaps live side by side in the social practices of the school. In the analysis it was evident that information literacy is not seen as a given dimension of literacy in general, in the way Säljö (2005, chap.7) and Andersen (2006) emphasize. Instead, fiction seems to be the predominant tool in the work with children's literacy, at least according to the librarian and is partly endorsed by the teachers, too. The more research-like working methods in the second formers' classrooms, which were influenced by a representative of the commercial sector (cf. Kapitzke 2003), can be contrasted with the work with fiction. Even though both the librarian and the teachers were actively involved in the children's seeking of information in connection with problem-centred assignments, ICT-related issues were supervised by a man with an entrepreneurial background without any pedagogical training and somewhat different views on the young children's abilities regarding information seeking. In the study by Davidsson et al. (2007) the use of ICT-tools for information seeking seemed to come into conflict with values inherent in the teachers' and the librarians' occupational identities. The view that it is not suitable for young children to carry out utilitarian information seeking is also evident in the present study.
This question regarding aesthetics and utility is in fact an epistemological question regarding the role of elementary school for young school children. For the elementary school teachers in this study fiction seems to function as a counterbalance to the stress they mean that the children are suffering from. According to the teachers, the school needs to offer a kind of sanctuary from an outer stressful society. This view clashes somewhat with other discourses where it is stressed that children need to be prepared for their lives in an information society where they need to know how to navigate to avoid drowning in the flood of information.

What do these descriptions and ways of organizing teaching imply for what it means to be an information literate pupil in elementary school?

From the findings it can also be discussed what kinds of information literacy the social practice of problem-centred teaching supports. Even though the origins of published documents (Simmons 2005; Kapitzke 2003; Pawley 2003) are discussed during the children's work with research, information seeking seems to be reduced to a set of procedures that might not support the children's development of the kind of understanding of information seeking that the pedagogues are aiming for. Earlier studies (e.g. Alexandersson \& Limberg 2003) have shown the importance of support during the formulation of research questions and have also problemized the copy-and-paste strategies which often arise when students work with problem-centred assignments. Limberg (2005) has also shown that a conception of information seeking as fact-finding interacts with poor learning outcomes. In the research procedure that emerged in the analysis, it is evident that the children's research questions were not seen as very important; instead the procedure of copying facts from books and Web pages comes into focus. One reason for this might be that the pedagogues do not have enough time for thoroughly discussing issues of researchable questions or the evaluation of the sources with every individual child. Thus, there is not much room for examining, for example, contradictions in the sources. This means that the children, who at the same time as they learn to do research also learn what it means to be a pupil in 
school, understand information seeking in a certain way within this particular social practice.

\section{Implications for further research}

Since the division between information literacy and ICT activities, and literacy and aesthetic activities have been found in both the present study and the study which initiated it (Davidsson et. al. 2007) we find it impossible to neglect. Instead we maintain that these empirical findings need to be highlighted and explored to a fuller extent. What implications do these two discourses have for the concept of information literacy? Jarkko Kari and Jenna Hartel (2007) claim that information science has been too focussed on utilitarian information seeking and has therefore neglected to develop models that would facilitate further understanding of information seeking related to aesthetics. Is it possible that the information literacy concept with its origins in industry and trade excludes issues that are important for a fuller understanding of the concept of information literacy, as a dimension of the wider notion of literacy? Are the two discourses really contradictory or can we rethink the information literacy concept to include information seeking related to aesthetics, such as fiction?

The empirical findings also suggest a further question for discussion which has to do with the potential of pictures for information seeking. Seeking pictures is an activity which has changed through the introduction of new ICT-tools. For the younger children, who are still on their way to capturing the written language, pictures seem to be an important part of their information seeking. Is it possible that the seeking of pictures can act as a bridge between the two discourses of literacy and information literacy? Often, questions about information literacy address textual sources and material. In further discussion we see the need for taking other kinds of media into account.

In this study, as well as in the study by Davidsson et al. (2007) we have mainly taken the perspective of the pedagogues in elementary school. Thus, the implications of their conceptions of information literacy and ICT-tools for the children's learning have not been fully explored in these studies. Therefore, it might also be interesting to adopt a children's perspective on questions re- garding information literacy and the use of ICT in elementary school.

\section{Notes}

1. The writing of this article has been conducted at The Linnaeus Centre for Research on Learning, Interaction and Mediated Communication in Contemporary Society (LinCS) and it was made possible by funding from Södra Älvsborgs Forskningsstiftelse and the Nordic Research School in Library and Information Science (NORSLIS). We would also like to thank Elin Olson, undergraduate student at Swedish School of Library and Information Science, for her help during the focus group session and doctoral candidate Frances Hultgren for her eminent assistance on issues concerning the English language.

2. "Pedagogues" refers to school staff such as elementary school teachers, pre-school teachers, school librarians, recreation leaders and ICT-assistants, who all have pedagogical roles with regard to children's seeking and use of information.

3. Trained teacher with 10 credits in LIS. Henceforth, the teacher-librarian will be referred to as "the librarian".

4. Pre-school group is an optional form for six year olds aiming at integrating pre-school and compulsory school.

5. The Swedish term information literacy, "informationskompetens", is not widespread outside universities, colleges and high schools in Sweden. Therefore the concept had to be discussed in other terms, for example "the fourth basic skill" (Rask 2000).

\section{References}

Alexandersson, M., and L. Limberg. 2003. Constructing meaning through information artefacts. The New Review of Information Behaviour Research 4: 17-30.

Andersen, J. 2006. The public sphere and discursive activities: Information literacy as sociopolitical skills. Journal of Documentation 62(2): 213-28.

Bawden, D. 2001. Information and digital literacies: A review of concepts. Journal of Documentation 57(2): 218-59.

Bruce, C. 1997. The seven faces of Information literacy. Adelaide: Auslib Press.

Davidsson, B., L. Limberg, A. Lundh, and L. Tyrén. 2007. Informationssökning som diskursiv och social praktik i de yngsta skolbarnens rum för lärande. [Information seeking as a discursive and social practice 
in the learning rooms of young school children.] $\mathrm{Hu}$ manIT 9(2): 76-133. URL: http://www.hb.se/bhs/ ith/2-9/bdllallt.pdf [viewed January 31, 2008].

Gee, J. P. 2002. A sociocultural perspective on early literacy development. In: Neuman, S.B. and D.K. Dickinson, eds. Handbook of Early Literacy Research, 30-42. New York: The Guilford Press.

Kapitzke, C. 2003. (In)formation literacy: A positivist epistemology and a politics of (out)formation. Educational Theory 53(1): 37-53.

Kari, J., and J. Hartel. 2007. Information and higher things in life: Addressing the pleasurable and the profound in information science. Journal of the American Society for Information Science and Technology 58(8): 1131-1147.

Limberg, L. 2005. Experiencing information seeking and learning: Research on patterns of variation. In: T. Wilson and E. Maceviciute, eds. Introducing information management: An information research reader, 68-80. London: Facet Publishing.

Marcum, J. W. 2002. Rethinking information literacy. Library Quarterly 72(1): 1-26.

Pawley, C. 2003. Information literacy: A contradictory coupling. Library Quarterly 73(4): 422-52.

Rask, S. R. 2000. Med eller utan filter?: Personliga funderingar kring etiken, pedagogiken, källkritiken och vuxenrollen när Internet kommer till skolan. [With or without filters?: Personal thoughts on the ethics, pedagogy, evaluation of sources and the role of the adults when Internet enters school. Stockholm: Stiftelsen för kunskaps- och kompetensutveckling. URL: http://www.kks.se/ upload/publikationsfiler/it_i_utbildning/med_eller_utan_filter_2000_publ.pdf. [viewed July 3, 2007].

Säljö, R. 2000. Lärande i praktiken: Ett sociokulturellt perspektiv. [Learning in practice: A sociocultural perspective]. Stockholm: Prisma.

Säljö, R. 2005. Lärande och kulturella redskap: Om lärprocesser och det kollektiva minnet. [Learning and cultural tools: About learning processes and the collective memo$r y]$. Stockholm: Norstedts akademiska förlag
Simmons, M. H. 2005. Librarians as disciplinary discourse mediators: Using genre theory to move toward critical information literacy. Portal: Libraries and the Academy 5(3): 297-311.

Sundin, O. 2005a. Webbaserad användarundervisning: ett forum för förhandlingar för bibliotekariers professionella expertis. Human IT 7(3): 109-168.

Sundin, O. 2005b. Conflicting approaches to user information seeking education in Scandinavian Webbased tutorials. In: Grove, A, ed. ASIST 2005: Proceedings of the 68th ASISET Annual Meeting. Medford, N. J.: American Society for Information Science and Technology.

Sundin, O. 2008. Web-based tutorials for information literacy as a forum for negotiations on information seeking expertise. Journal of Documentation 64(1): 2444.

Sundin, O., and J. Johannisson. 2005. Pragmatism, neopragmatism and sociocultural theory: Communicative participation as a perspective in LIS. Journal of Documentation 61(1): 23-43.

Tuominen, K., R. Savolainen, and S. Talja. 2005. Information literacy as a sociotechnical practice. Library Quarterly 75(3): 329-45.

Vygotsky, L. S. 1978. Mind in society: The development of higher psychological processes. Cambridge, MA: Harvard University Press.

Vygotsky, L. S. 1997. The instrumental method in psychology. In: R.W. Reiber and J. Wollock, eds. The collected works of L.S. Vygotsky. Vol. 3, Problems of the theory and history of psychology: Including the chapter on the crisis in psychology, 85-90. New York: Plenum Press.

Wertsch, J. V. 1998. Mind as action. New York, NY: Oxford University Press.

Williams, D. A. and C. Wavell. 2006. Information literacy in the classroom: secondary school teachers' conceptions. Aberdeen: The Robert Gordon University. URL: http://www.rgu.ac.uk/abs/research/page. cfm?pge=13088 [viewed 27 March 2008\}.

\section{Editorial history:}

Paper received 3 October 2007;

Accepted 4 December 2007. 


\section{Appendix \\ Compilation of analyzed material.}

\begin{tabular}{|c|c|c|c|}
\hline Type of material & Date & Participants/authors & Researcher \\
\hline Focus group interview & September 21, 2006 & 4 primary-school teachers & $\begin{array}{l}\text { Anna Lundh, Elin } \\
\text { Olson }\end{array}$ \\
\hline Individual interview & October 20, 2006 & IT assistant & Anna Lundh \\
\hline Individual interview & November 13,2006 & Teacher librarian & Anna Lundh \\
\hline $\begin{array}{l}\text { Sheets of information seeking } \\
\text { exercises }\end{array}$ & - & IT assistant & Anna Lundh \\
\hline $\begin{array}{l}\text { Written goals of the school } \\
\text { library }\end{array}$ & - & $\begin{array}{l}\text { Teacher librarian (main } \\
\text { author) }\end{array}$ & Anna Lundh \\
\hline $\begin{array}{l}\text { Written plan for development } \\
\text { work of the library }\end{array}$ & - & $\begin{array}{l}\text { Teacher librarian (main } \\
\text { author) }\end{array}$ & Anna Lundh \\
\hline Observation & October 6, 2006 & $\begin{array}{l}2 \text { primary-school teachers, } 3 \\
\text { pre-school teachers, } 1 \text { music } \\
\text { teacher, } 1 \text { trainee and school } \\
\text { children from } 2 \text { first grade } \\
\text { classes and } 1 \text { pre-school class. }\end{array}$ & Anna Lundh \\
\hline Observation & October 13, 2006 & $\begin{array}{l}2 \text { primary-school teachers, } 4 \\
\text { pre-school teachers, } 1 \text { music } \\
\text { teacher, } 2 \text { trainees and school } \\
\text { children from } 2 \text { first grade } \\
\text { classes and } 1 \text { pre-school class. }\end{array}$ & Anna Lundh \\
\hline Observation & October 20, 2006 & $\begin{array}{l}2 \text { primary-school teachers, } 4 \\
\text { pre-school teachers, } 1 \text { music } \\
\text { teacher and school children } \\
\text { from } 2 \text { first grade classes and } \\
1 \text { pre-school class. }\end{array}$ & Anna Lundh \\
\hline Observation & October 27, 2006 & $\begin{array}{l}2 \text { primary-school teachers, } 4 \\
\text { pre-school teachers, } 1 \text { music } \\
\text { teacher, } 1 \text { supply teacher, } 1 \\
\text { Work Experience Scheme } \\
\text { trainee and school children } \\
\text { from } 2 \text { first grade classes and } \\
1 \text { pre-school class. }\end{array}$ & Anna Lundh \\
\hline Observation & October 11, 2006 & $\begin{array}{l}2 \text { primary-school teachers, } 1 \\
\text { teacher librarian, school } \\
\text { children from } 2 \text { second grade } \\
\text { classes. ( } 1 \text { IT assistant, } 1 \\
\text { recreation leader). }\end{array}$ & Anna Lundh \\
\hline Observation & November 13, 2006 & $\begin{array}{l}2 \text { primary-school teachers, } 1 \\
\text { teacher librarian, } 1 \text { recreation } \\
\text { leader, } 1 \text { volunteer from the } \\
\text { Red Cross, school children } \\
\text { from } 2 \text { second grade classes. }\end{array}$ & Anna Lundh \\
\hline
\end{tabular}

